\title{
LEXICON
}

\author{
VOLUME 3 \\ Number 2, October 2014 \\ Page $125-136$
}

\section{REFUSAL STRATEGIES PERFORMED BY SPEAKERS OF DIFFERENT AGES}

\author{
Citra KinantiKayang
}

\begin{abstract}
This pragmatic research was conducted to identify and classify the refusal strategies performed by two groups of speakers of different ages. It was also conducted to investigate the differences and similarities in the strategies. The first group consisted of 20 speakers aged 17-27 years old and the second group consisted of 20 speakers aged 40-50 years old. There were 240 refusals performed as the data of this research which were classified according to the classification proposed by FelixBradesfer (2008). This research foundthat there were 9 direct refusals, 45 indirect refusals, and 66 adjuncts to refusals performed by the younger speakers. There were 7 direct refusals, 49 indirect refusals, and 64 adjuncts to refusals that were performed by the older speakers. This research also found that there were more similarities than differences on the refusal performed by the two groups.
\end{abstract}

Keywords: Pragmatics, context, speech acts, refusals, refusal strategies, different age groups

\section{INTISARI}

Kajian pragmatik ini dilaksanakan untuk mengindentifikasi dan mengelompokkan strategistrategi penolakan yang digunakan oleh penutur dari dua kelompok yang berbeda usia. Kajian ini juga meneliti perbedaan dan persamaan dalam strategi-strategi tersebut. Kelompok pertama terdiri dari 20 penutur yang berumur 17-27 tahun. Kelompok kedua terdiri dari 20 penutur yang berumur 40-50 tahun. Ada 240 penolakan yang telah dituturkan sebagai data kajian ini yang telah diklasifikasikan sesuai dengan klasifikasi yang diusulkan oleh FelixBradesfer (2008). Kajian ini menunjukkan 9 penolakan langsung, 45 penolakan tidak langsung, dan 66 penolakan dengan tambahan-tambahan yang penting yang dituturkan oleh kelompok yang lebih muda. Terdapat 7 penolakan langsung, 49 penolakan tidak langsung, dan 64 penolakan dengan tambahan-tambahan penting yang dituturkan oleh kelompok yang lebih tua. Kajian ini menunjukkan bahwa lebih banyak persamaan daripada perbedaan pada penolakan-penolakan yang tertuturkan oleh kedua kelompok.

Kata kunci: Pragmatik, konteks, tindak tutur, penolakan, strategi-strategi penolakan, dua kelompok yang berbeda usia 


\section{BACKGROUND OF CHOOSING THE SUBJECT}

As a young person, the present writer finds it difficult to refuse appropriately. That is why it is intriguing to find different refusals strategies performed by people of different ages. An interesting fact is that other speech acts can be used as ways of refusing. Therefore, other speech acts will also beinvestigated. Many studies have been conducted on refusal whichfocused more on comparing refusals that were performed by people from two or more different nationalities. Theywere conducted to prove how different cultural backgrounds affected people's performances in refusing something. This study, on the other hand, aims at looking into refusal strategies performed by two groups of people from different ages in refusing certain invitations, offers, and requests.

The groups were younger group, consisting of speakers of 18-28 years oldand older group, consisting of speakers of 40-50 years old. This researchwas conducted to know whether there were any similarities or differences in the refusals performed by these two groups. The data for this study were collected through DCT (Discourse Completion Task). The younger respondents of this studywere all Indonesians, but the older respondents came from different countries; Indonesians, Indians and Pakistanis who were not native speakers of English. However, this study will not relate to the different nationalities. As stated before, it will focus only on the age difference. The reason why different nationalities are not taken into consideration is because those countries are Asian countries. As it is stated in "The Amazing Cultures the Different Parts of Asia" that south-eastern and westernAsian countries have similar cultures and customs because they experienced the same conditions.

Refusal itself is defined as a negative conduct to an offer, request, invitation,or suggestion (Abdul Satar, CheLah, \& Raja Suleiman 70).According to Felix-Bradesfer these strategies are divided into three types: direct, indirect refusal, and adjunct to refusal strategies.

This research is conducted based on the following objectives;

1. to identify and classify refusal strategies chosen by two groups of different ages; and

2. to investigate the differences and similarities on the strategies performed by the two groups.

This study focuses on the study of the speech act of refusal. The analysis of this paper is limited only to the identification and classification of direct and indirect refusal strategies, and adjuncts to refusal strategies.This study also will not deal with the correctness and incorrectness of the grammar used in refusals performed by the respondents.

The data for this study were collected through Discourse Completion Task (DCT). The DCT contained 6 questions with different situations of requests, invitations and offers, and then they were distributed to 40 respondents. The respondents were asked to refuse all the requests, invitations and offers. The DCT had six situationsconsisting of two situations of requests, two invitations and two offers. The first situation is assumed to be asked someone with a higher position, the second situation is assumed to be asked by a mother. The third and the forth situations are assumed to be asked by a very close friends, and the two last situations are asked by a very young family member with aged around 3-5 years old. The DCT also contains four additional questions which were added to give the writer the idea on the respondents' English proficiency.

From the filled DCTs, the refusals were firstly recapitulated according to each situation. After that, the 240 refusals were classified into direct refusal strategy, indirect refusal strategy, or adjunct to refusal strategyas proposed by Felix-Bradesfer (2008). Then, the refusals were again recapitulated to know the number of the strategies performed. Finally, through those tables, the differences and similarities in how the two groups performed refusals will be discussed. 


\section{REFUSALS}

The data of this researchare classified according to the refusal classification proposed by J. Cesar Felix-Bradesfer (73-81). Below are the classification and the examples of the refusals:

$i$. Direct Refusal is a strategy used when a speaker refuses with just a "no" or with negation of a proposition.

A. A flat "no"

1. No, I totally made plans with my family, I gotta go out.

B. Negation of a proposition

Examples:

2. I can't come to the party.

3. It is impossible for me to attend the party.

ii. Indirect Refusal is a strategy performed through other speech acts.

A. Mitigated Refusal

Examples:

4. Unfortunately, I won't be able to attend your farewell party.

5. So, I think probably, I am not gonna take the class.

B. Reason/Explanation

Examples:

6. I have plans.

7. I am having dinner with my parents who are visiting for the weekend.

C. Indefinite Reply

Examples:

8. Oh, I don't know if I can come to your party.

9. Let me see if I can, I can't promise you anything.

D. Apology/

Examples:

10. I'm really sorry, I can't come

11. I apologise, but uh, my shift says I'm done at 7.00 p.m.
E. Alternative

Examples:

12. Why don't we go out for dinner next week?

13. How about if we agree to do, let's say halfofthe work and then on Monday, really early,...

F. Postponement

Examples:

14. Um, is it possible I could come in early on Monday?

15. I'll think about it and I'll let you know later.

G. Repetition of Part of Previous Discourse Example:

16. a: Check this out, next Friday, my house 8 p.m., my $21^{\text {st }}$ birthday party, man, all the old crew's gonna be there, it's gonna be fantastic, you gotta come.

b: What? Next Friday? [ $\leftarrow$ repetition]

a: Next Friday, 8p.m.

b: I'll tell ya what, I can't, man.

H. Request for Additional Information Example:

17. What time is the party?

18. Oh well, I don't know, who - who all is going to be there?

I. Set Condition for Future or Past Acceptance

Examples:

19. If you had asked me earlier, I would have accepted.

20. If I find someone to give me a ride to your party, I'll be there after work.

J. Wish

Examples:

21. I wish I could stay and work for two more hours, may be next time. 
22. I wish I were able to go, but I already have plans.

K. Promise to Comply

Examples:

23. I'm gonna try to be at your party, but I can't promise you anything.

24. I'm gonna try to find a way around it, even if it's to get there just to give you a hug and,...

L. Preparator

Examples:

25. I'll be honest with you, I really would prefer not to.

26. You know what? I'm gonna be out of town, and I just can't.

iii. Adjunct to Refusals is a strategy used when an adjunct is added before a refusal.

\section{A. Positive Opinion}

Examples:

27. That's a good idea, but I don't think I'll be able to make it.

28. Congratulations on your promotion, but...

B. Willingness

Examples:

29. I'd love that, but...

30. I would love to go to celebrate it, but...

\section{Gratitude/Appreciation}

Examples:

31. Thanks for the invitation, but I already have plans.

32. I really appreciate the offer, but I have prior engagements.

D. Agreement

Examples:

33. Yes/okay, but...

34. It's fine, but...

E. Empathy

Examples:

35. I understand you are in a pitch, but...

36. The situation that we find ourselves in is really understandable, but...

\section{RESULTS AND DISCUSSION}

Collectedusing the DCTs, thedata contained six situations of requests, invitations, and requests. They were firstly recapitulated according to each situation. The data were then classified into different strategies of direct and indirect refusals, and adjunct to refusals and presented according to each situation. The tendency of how their performances were different or similar is shown through the numbers in the tables. Table 1 below shows the number of refusal strategies performed by the speakers from the both groups.

Table 1.Refusal strategies performed by the 40 speakers

\begin{tabular}{|l|c|c|}
\hline \multicolumn{1}{|c|}{ Strategies } & Younger Group & Older Group \\
\hline Direct Refusal & 8 & 3 \\
\hline A flat "No" & 1 & 4 \\
\hline Negation of a proposition & \multicolumn{2}{|l|}{} \\
\hline Indirect Refusal & 24 & 19 \\
\hline Apology/Regret & 1 & 2 \\
\hline Wish & 7 & 12 \\
\hline Reason/Explanation & 3 & 8 \\
\hline Indefinite Reply &
\end{tabular}




\begin{tabular}{|c|c|c|}
\hline $\begin{array}{l}\text { Request for Additional } \\
\text { Information }\end{array}$ & 1 & 1 \\
\hline Alternative & 9 & 3 \\
\hline $\begin{array}{l}\text { Set Condition for Past } \\
\text { Acceptance }\end{array}$ & - & 1 \\
\hline Preparator & 1 & - \\
\hline$\frac{\text { Repetition of Part of Previous }}{\underline{\text { Discourse }}}$ & - & 3 \\
\hline \multicolumn{3}{|l|}{ Adjuncts to Refusals } \\
\hline Gratitude & 22 & 27 \\
\hline Willingness & 13 & 6 \\
\hline Agreement & 3 & 3 \\
\hline Positive Opinion & 20 & 23 \\
\hline Empathy & 7 & 5 \\
\hline TOTAL & 120 & 120 \\
\hline
\end{tabular}

Felix-Bradesfer mentioned that there were two strategies of direct refusals, twelve strategies of indirect refusals, and five strategies of adjuncts to refusals. Table 1 shows that out of the 240 refusals, there were only sixteen refusal strategies which were performed by the speakers. In performing the direct refusals, there were more speakers of the younger group who refused by the flat "no", but more respondents of the older group who refused by the negation of a propositions.
In performing indirect refusals, there were more respondents of the younger group who refused by employing apologies and giving alternatives. However, in performing the adjuncts of refusals, there were more respondents of the younger group who refused by indicating their willingness and showing empathy.

\section{FIRST SITUATION}

In the first situation, the respondents had to pretend to be a worker who was requested to attend a dinner gathering by a supervisor and they had to refuse this request.

\begin{tabular}{|l|c|c|}
\hline \multicolumn{1}{|c|}{ Strategies } & Younger Group & Older Group \\
\hline Direct Refusal & - & 2 \\
\hline Indirect Refusal & \multicolumn{2}{|c|}{} \\
\hline Apology/Regret & - & 1 \\
\hline$\underline{\text { Repetition of Part of }}$ & \multicolumn{2}{|c|}{} \\
\hline$\underline{\text { Previous Discourse }}$ & 1 & 1 \\
\hline$\underline{\text { Wish }}$ & \multicolumn{2}{|c|}{} \\
\hline Adjuncts to Refusal & 8 & 7 \\
\hline$\underline{\text { Gratitude }}$ & 4 & 4 \\
\hline$\underline{\text { Willingness }}$ & 2 & 1 \\
\hline$\underline{\text { Positive Opinion }}$ & $\mathbf{2 0}$ & $\mathbf{2 0}$ \\
\hline Empathy & & 4 \\
\hline Total & & \\
\hline
\end{tabular}


The result shows that in refusing a request from someone with a higher position, there was no respondent using the direct refusal strategy. Most respondents from both groups used expression of gratitude, which was thanking the supervisor for the request (e.g., "Thank you very much,..."). There were four people from both groups refused by showing willingness to accept the request which was then followed by the actual refusal (e.g., "I would love to go,...”). Another four younger respondents refused by apologising for not able to accept the request (e.g., "I'm terribly sorry, sir,...") and only two respondents from the older group refused in this strategy. There was one respondent from each group who refused by making a wish to accept the request (e.g., "I wish I could,..."). The table also shows that there were four older respondents who refused the request by giving a positive opinion towards the request, (e.g., "Sir, With all due respect,...”), but there were only two younger respondents who refused using this strategy. There was one respondent from each group who refused by showing empathy (e.g., "It's a pity that I can't attend the dinner,...)to show involvement towards the request. There was only one respondent from the older group who refused by repeating the request to show the supervisor that he/she was actually paying attention to the request (e.g., "Dear Sir,you had invited me to take dinner along with company workers,...)

\section{SECOND SITUATION}

In the second situation, the respondents had to pretend to be a child who was invited by his/her mother to join her and her friends for lunch. However, the invitation had to be turned down because the respondents have bought their favourite meal for lunch. In this situation, the respondents had to refuse an invitation from someone older and with a very close relation.

\begin{tabular}{|c|c|c|}
\hline Strategies & Younger Group & Older Group \\
\hline Direct Refusal & 2 & 1 \\
\hline \multicolumn{3}{|l|}{ Indirect Refusal } \\
\hline Apology/Regret & 7 & 7 \\
\hline $\begin{array}{l}\text { Repetition of Part of } \\
\text { Previous Discourse }\end{array}$ & - & 1 \\
\hline$\underline{\text { Reason/Explanation }}$ & 3 & 2 \\
\hline$\underline{\text { Alternative }}$ & 2 & 1 \\
\hline \multicolumn{3}{|l|}{ Adjuncts to Refusal } \\
\hline$\underline{\text { Gratitude }}$ & 1 & 5 \\
\hline Willingness & 4 & - \\
\hline Positive Opinion & 1 & 3 \\
\hline Total & 20 & 20 \\
\hline
\end{tabular}


The result shows that most respondents refused an invitation from someone older and with a very close relationship by employing an apology. There were two younger respondents and one older who refused the invitation directly (e.g., "No, I'm fine, Mom,..."; ;"Mom, I can’t join,...”). Three younger respondents chose to refuse such invitation by giving explanation and only two older respondents use the same strategy (e.g., "Mom, I already have my favourite chicken burger and fries,..."). However, there were five older respondents who refused the invitation by showing gratitude towards their mothers and only one younger respondent used this strategy. There were two younger respondents who refused by giving alternative, but only one older respondent refused by the same strategy (e.g., "Mom,may I not join you and your friends?”). There was an older respondent who refused the invitation by repeating the invitation to show the mother that he/she paid attention to the invitation. There were three respondents from the older group and one younger respondent who refused by showing positive opinion towards the invitation. Four younger respondents refused by showing their willingness to actually accept the invitation and none of the older respondent refused by the same strategy (e.g., 'Mom, I would love to join you,...").

\section{THIRD SITUATION}

In the third situation, the respondents had to pretend to be a friend who was offered lasagna from their best friend. However, just before meeting that best friend, the respondent had a big meal, so they had to refuse the offer.

\begin{tabular}{|l|c|c|}
\hline \multicolumn{1}{|c|}{ Strategies } & Younger Group & Older Group \\
\hline Direct Refusal & 1 & 1 \\
\hline Indirect Refusal & 1 & 1 \\
\hline$\underline{\text { Apology/Regret }}$ & - & 1 \\
\hline$\underline{\text { Reason/Explanation }}$ & - & 1 \\
\hline$\underline{\text { Request for Additional }}$ & \multicolumn{2}{|c|}{} \\
\hline$\underline{\text { Information }}$ & 1 & 1 \\
\hline$\underline{\text { Alternative }}$ & - & - \\
\hline$\underline{\text { Indefinite Reply }}$ & 1 & \\
\hline \multicolumn{1}{|c|}{ Preparator } & \multicolumn{2}{|c|}{} \\
\hline Adjuncts to Refusal & 3 & 5 \\
\hline Gratitude & 1 & 8 \\
\hline Willingness & 11 & - \\
\hline Positive Opinion & 1 & $\mathbf{2 0}$ \\
\hline Empathy & $\mathbf{2 0}$ & \\
\hline Total & & \\
\hline
\end{tabular}


The table above shows that in refusing an offer from someone who was at the same age and havea very close friendship with the speaker, most respondents use positive opinions (e.g., "Wow! That looks delicious, ...")to complement the offer before actually refusing it. There was one respondent from each group who directly refused the offer. Five older respondents and three younger respondents refused the offer by thanking their best friends for the offer. From both groups there was one respondent who refused the offer by giving alternative, employing apology, and showing willingness. The table also shows that there was only one respondent from the younger group who refused by showing empathy(e.g., "Oh this is my worst day ever!")and by preparing his/her interlocutor for ensuing the refusal (e.g., "To be honest,...”). Also, there was one older respondent who refusedusing each ofthese strategies, they were requesting for additional information strategy (e.g., "Why you don't let me know previously?"), giving an indefinite reply (e.g., "Don't command me to eat this,..."), and giving explanation.

\section{FOURTH SITUATION}

In the fourth situation, the respondents had to pretend to be a friend who wasinvited by his/her best friend to attend his/her engagement party. Sadly, at the same day and at the same time, the respondent's sister was also having her engagement party, so they had to refuse the invitation.

\begin{tabular}{|l|c|c|}
\hline \multicolumn{1}{|c|}{ Strategies } & Younger Group & Older Group \\
\hline Direct Refusal & - & - \\
\hline \multicolumn{2}{|l|}{ Indirect Refusal } \\
\hline Apology/Regret & 8 & 4 \\
\hline Reason/Explanation & - & 4 \\
\hline$\underline{\text { Wish }}$ & - & 1 \\
\hline$\underline{\text { Indefinite Reply }}$ & 2 & - \\
\hline \multicolumn{1}{|l|}{ Set Condition for Past } & - & 1 \\
\hline Acceptance & & \\
\hline Adjuncts to Refusal & 2 & 2 \\
\hline Gratitude & 2 & 1 \\
\hline Willingness & 2 & 3 \\
\hline Positive Opinion & 4 & 4 \\
\hline Empathy & $\mathbf{2 0}$ & $\mathbf{2 0}$ \\
\hline Total & & \\
\hline
\end{tabular}

The table above shows that in refusing an invitation from a best friend who was at the same age and have a very close friendship, to attend his/her engagement party, none of the respondent refused it directly. Younger respondents, eight of them, refused it by employing apology for not able to attend the party, and only four older respondents refused using the same strategy. Four respondents of both groups showed empathy to refuse the invitation to show how they really feel towards refusing the invitation (e.g., "My best friend, I hope you understand that I can't go,...").

Table 5 also shows that there were two younger respondents and three older respondents refused such invitation by giving positive opinions towards it (e.g., "Congratulations on your engagement!"). There were two younger respondents who refused it by giving an indefinite reply(e.g., "What a nice day, everybody is getting engaged today,...") and no older respondent who refused using the same strategy. Two respondents from both groups refused the invitation by first showing their gratitude towards 
the invitation. Two younger respondents and one older respondent refused the invitation by showing their willingness to accept the invitation. The table also shows that there were four respondents from the older group who refused it by giving explanations. Only one respondent also from the same group refused it by expressing a wish that they could accept the invitation and by settingcondition for past acceptance (e.g., "Ifonly I could come to your party, I wouldn't miss it!")

\section{FIFTH SITUATION}

In the fifth situation, the respondents had to pretend to be a cousin who was offered a cake by his/her five years old cousin. Sadly, the cake doesn't look delicious at all and they have no desire to eat it whichwas why they have to refuse it.

\begin{tabular}{|c|c|c|}
\hline Strategies & Younger Group & Older Group \\
\hline Direct Refusal & 5 & 2 \\
\hline \multicolumn{3}{|l|}{ Indirect Refusal } \\
\hline Apology/Regret & - & 1 \\
\hline Reason/Explanation & 1 & 1 \\
\hline $\begin{array}{l}\text { Request for Additional } \\
\text { Information }\end{array}$ & 1 & - \\
\hline $\begin{array}{l}\text { Repetition of Previous } \\
\text { Discourse }\end{array}$ & - & 1 \\
\hline Alternative & - & 1 \\
\hline \multicolumn{3}{|l|}{ Adjuncts to Refusal } \\
\hline Gratitude & 8 & 8 \\
\hline Agreement & 1 & 1 \\
\hline Positive Opinion & 3 & 5 \\
\hline Empathy & 1 & - \\
\hline Total & 20 & 20 \\
\hline
\end{tabular}

Table 6 shows that in refusing an offer from someone much younger with a close relationship most respondents refused it by showing gratitude towards the offer (e.g., "Thank you cousin,..."). There were five younger respondents and two older respondents who directly refused the offer (e.g., "No, thanks baby..."). Three of younger respondents and five of older respondents chose to refuse the offer by giving positive opinion towards the cake, which doesn't look delicious at all. There was one from each group who refused the offer by giving an explanation and expressing an agreement (e.g., "I'm fine. Thank...") to show an interest towards the offer. The table also shows that there was one younger respondent who refused the offer by expressing empathy. There was one older respondent who refused the offer by each of these strategies, they were by repeating the offer, giving an alternative (e.g., "Hey dear, the full cake is for you alone, eat all and enjoy"), and employing an apology. There was also one younger respondent who refuse this offer by requesting additional information (e.g., "Is this the famous intergalactic cake that you brought me?')

\section{SIXTH SITUATION}

In the sixth situation, the respondents had to pretend to be an older sister or an older brother who has a three year old sisterwho was crying requesting the respondents to play Barbie with her. However, the respondents had to refuse this request because they have an important presentation the next day. 


\begin{tabular}{|l|c|c|}
\hline \multicolumn{1}{|c|}{ Strategies } & Younger Group & Older Group \\
\hline Direct Refusal & 1 & 3 \\
\hline \multicolumn{2}{|l|}{ Indirect Refusal } \\
\hline Apology/Regret & 4 & 4 \\
\hline Reason/Explanation & 3 & 4 \\
\hline Indefinite Reply & 1 & 7 \\
\hline Alternative & 6 & - \\
\hline Adjuncts to Refusal & 2 & 2 \\
\hline Agreement & 1 & - \\
\hline Positive Opinion & 2 & - \\
\hline Willingness & $\mathbf{2 0}$ & $\mathbf{2 0}$ \\
\hline Total &
\end{tabular}

Table 7 shows that in refusing an offer from someone much younger with a veryclose relationship, six younger respondents refused it by giving an alternative for the request (e.g., "SweetyyyyI have a Barbie movie and you will absolutely love it coz it's amazing,") and none of the older respondent uses this strategy. Seven older respondents refused the request by giving an indefinite reply (e.g., "Don't cry like that,...”), but only one younger respondent refused by the same strategy. There were altogether four respondents who directly refused the request. Three younger respondents and four older respondents refused by giving explanations. There were four respondents from both groups who refused the request by employing an apology. Two younger respondents and two older respondents refused by an agreement to accept the request however followed by an additional condition (e.g., "OK. But only 5 minutes...”). The table also shows that there were two younger respondents who refused this request by showing their willingness to actually accept the request and there was also one respondent who refused by showing a positive opinion towards the request.

\section{THE DIFFERENCES AND SIMILARITIES OF THE REFUSALS PERFORMED BY THE TWO GROUPS}

From the result above, it could be seen that there were more similarities than differences between the refusals performed by the two groups of people from different ages. The first situation was where the respondents had to refuse a request performed by someone with a higher position. In this situation, none of the respondents refused it directly.Even though some of the older respondents were older than the person with the request, no older respondent refused it directly. Most respondents from both groups refused it by showing their gratitude towards the request. The writer assumes that this was done to show more respect to the person with the request since he/she was someone with a higher social position.

In the second situation, the result shows that in refusing an invitation from someone older with a very close relationship, most respondents from both groups refused the invitation by employing apology. The writer assumes that this was done to prevent the mother from being offended.As a gesture of politeness, there were younger respondents than the older respondents who refused the invitation by giving out explanation. Another interesting result was that there were no older respondentswho refused it by showing their willingness to accept the invitation.

The third and fourth situationswere where the respondents had to refuse an offer and an invitation from someone of the same age with a close relationship. In refusing the offer most respondents from both groups refused it by showing positive opinion towards the offer. The writer assumed that this was done to respect the offer from their friends. 
The result from both groups was very similar in refusing an offer in this situation. Whenrefusing an invitation of an important lifetime event, which was asked in the fourth situation, none of the respondents refused it directly. Most respondents from both groups refused this invitation by employing an apology. This was done to show that they really regret the fact that they had to skip an important event of their friend's life.

The fifth and the last situation were where the respondents had to refuse an offer and a request by two very young family members. In the fifth situation respondents were offered a cake which doesn't look delicious by their very young cousin. Towards this offer, most respondents from both groups refused it by showing their gratitude. The writer assumed that this was done to prevent their younger cousin from getting hurt of their refusals. There were more of the younger respondents who refused it directly. This can be assumed that younger people care less for the feelings of someone much younger. There were more of the older respondents who refused it by giving out positive opinions. This can be assumed that older people care more for the feelings of someone younger, perhaps because the older respondents have children of their own.

In the last situation, the respondents had to refuse a request from their crying little sister to play Barbie because they have an important presentation coming up. In refusing this kind of request, there were more of the older respondents who refused it directly. There were also more of the older respondents who refused it by giving an indefinite reply, but there were more of the younger respondents who refused by giving an alternative. The writer assumes that these strategies were done to prevent their little sister from crying out more. The same number of respondents from both groups refused it by agreeing to accept the request, but with an additional condition.

\section{CONCLUSION}

This research also shows that when refusing a request from someone with a higher social position, no respondents from both groups refused it directly. Most respondents from both groups refused it by expressing their gratitude towards the request. In refusing an invitation from the mother, who was someone older with a close relationship, two of the younger respondents and one of the older respondents refused it directly. Most of the respondents from both groups refused such invitation by employing an apology. As for refusing an offer from their friends, who was at the same age with close relationships, only one respondent from each group refused it directly. Most respondents from both groups refused it by giving positive opinions towards the offer before the actual refusals.

However, in refusing a life event's invitation also from a close friend, none of the respondents from both groups refused it directly. Most respondents from the younger group refused such invitation by employing their apologies for being not able to fulfil the invitation. The same number of respondents from the older group chose to refuse the invitation by showing empathy, giving explanations, and stating their apologies. In refusing an offer from a five years old cousin, five younger respondents and two older respondents refused it directly. The most number of respondents fromboth groups refused it by showing their gratitude towards the offer. Finally, in refusing a request from a crying little sister, aged three years old, only one respondent from the younger group and three respondents from the older group refused in directly. Younger respondents chose to refuse the request by giving alternatives but older respondents chose to refuse it by giving indefinite replies. Overall, there were more of the similarities than differences in the refusals performed by the respondents from the two groups of different ages. 


\section{REFERENCES}

Al Shboul, Yasser., Maros, Marlyna., M. Yasin, M. Subakir. "An Intercultural Study of Refusal Strategies in English between Jordanian EFL and Malay ESL Postgraduate Students."The Southeast Asia Journal of English Language Studies Vol 18, No 3 (2012): 2939. ejournals.ukm.my/3l/article/viewFile/ 1107/999. Web. 09 December 23.

Amarien, Novy. "Interlanguage Pragmatics: A Study of the Refusal Strategies of Indonesian Speakers Speaking English." TEFLIN Journal Vol 8, No 1 (1997). journal.teflin.org/index.php/teflin/ article.Web. 09 December 2013.

Anonym. "The Amazing Cultures The Different Parts of Asia-Asian Countries."Inminute.com. In Minute Online Magazine. Web. 09 June 2015.

Burhanuddin, Ahmad. "A Comparative Study on Refusal in English by Indonesian Learners and Native Speakers of English."Yogyakarta: Universitas Gadjah Mada, 2008. Unpublished Graduating Paper

C. Levinson, Stephen. Pragmatics. Melbourne: Cambridge University Press, 1983. Print

Felix-Bradesfer, J.Cesar. Politeness in Mexico and the United States. Philadephia: John Benjamin Publishing Company, 2008. Print
Guo, Yinling. "Chinese and American Refusal Strategy: A Cross-cultural Approach."Theory and Practice in Language Studies Vol 2, No 2 (2012): 247-256. ojs.academypublisher.com/ index.php. Web. 18 December 2013.

Nadar, F.X. Pragmatik dan Penelitian Pragmatik. Yogyakarta: Graha Ilmu, 2009. Print

Rahmatika. "Refusal as Used in Drama Movies in English."Yogyakarta: Universitas Gadjah Mada, 2013. Unpublished Graduating Paper

Richards, Jack C., Schmidt, Richard. Dictionary of language teaching \& applied linguistics. Norkfolk:Pearson Education Limited, 2002. Print

Satar, Abdul., Lah, Ceh., Suleiman, Raja. "Refusal Strategies in English by Malay University Students." Gema Only Journals of English Studies Vol 11, No 3 (2011): 69-81. journalarticle.ukm.my. Web. 09 December 2013.

Verscheuren, Jef. Understanding Pragmatics. New York: Oxford University Press, 1999. Print

Yule, George. The Study of Language. New York: Cambridge University Press, 2006. Print 